\title{
FORMATION OF THE FUTURE TEACHERS' PEDAGOGICAL IMAGE
}

УДК 378+371.15

DOI https://doi.org/10.32843/2663$6085 / 2020 / 28.26$

Гурін Р.C.,

канд. пед. наук,

доцент касредри педагогіки

Південноукраїнського національного

педагогічного університету

імені К.Д. Ушинського

Терзі п.п.,

канд. пед. наук,

доцент кафедри спортивних ігор

Південноукраїнського національного

педагогічного університету

імені К.Д. Ушинського

Яцій О.М.,

канд. пед. наук,

доцент кафедри педагогіки

Південноукраїнського національного

педагогічного університету

імені К.Д. Ушинського
Підвищення уваги до індивідуальності майбутніх учителів призводить до того, що високий рівень ссрормованості педагогічного іміджу може бути одним із найважливіших показників їх професійного становлення. Теоретичний аналіз наукового фронду в межах фрілософського, сочіологічного, психологічного та педагогічного напрямів дав змогу установити змістове наповнення конструкту «педагогічний імідж», який ототожнюють із такими багатозначними синонімічними рядами, як професійний імідж та імідж учителя. За допомогою аналізу психолого-педагогічної літератури встановлено, що фрормування педагогічного іміджу майбутніх учителів срізичної культури потребує свідомого підходу та постійного управління ним, яке передбачає імплементацію бажаних характеристик у його поведінкову форму, моти ваційно-ціннісну орієнтацію й комплексну систему оцінювання.

В аспекті дослідження подано авторську позицію щодо визначення чинників, які впливають на формування педагогічного іміджу майбутніх учителів під час їх профресійного становлення. Для реалізації мети дослідження здійснено діагностування рівнів сорормованості комунікативних умінь (сприяють швидкому й точному відображенню комунікативних ситуацій на уроках), педагогічної рефрлексії (сприяє як творчому підходу до професійної діяльності, так досягненню ії максимальної ефективності й результативності в професійному становленні майбутніх учителів) і мотиваціі на педагогічну діяльність (прагнення до постійного просресійного розвитку, неперервного вдосконалення рівня педагогічної майстерності) майбутніх учителів фрізичної культури. Упродовж дослідження встановлено, що найбільша кількість майбутніх учителів фрізичної культури (45\% від загальної кількості респондентів) засвідчила базовий рівень сфрормованості комунікативних умінь, педагогічної рефрлексіі та мотивації на педагогічну діяльність. На низькому рівні виявлено 34\% респондентів, на достатньому - 21\% майбутніх учителів фозичної культури.

Ключові слова: імідж, професійний імідж, педагогічний імідж, майбутні вчителі, моти- вація, педагогічна ресрлексія, комунікативні вміння.

The increased attention to the future teachers individuality proves that the high level of the formation of pedagogical image can be one of the most important indicators of their professional development. Theoretical analysis of the scientific fund within philosophical, sociological, psychological and pedagogical directions allowed to establish the meaningful content of the pedagogical image, which is associated with such polysemantic synonymic rows as professional image and teacher's image. Based on the analysis of psychological and pedagogical literature, it was found out that the formation of pedagogical image of the future physical education teachers requires a conscious approach and constant management, which involves the implementation of desired characteristics in its behavioral form, motivational and valuable orientation and complex assessment system.

In the aspect of the research, the author's position has been submitted for the definition of indicators, which have an influence on the formation of pedagogical image of the future teachers during their professional development. For the implementation of the research goal, the diagnosis of the formation of communicative skills was performed (which conduce to the rapid and accurate reflection of communicative situations in the classroom), as well as of pedagogical reflection (promotes both the creative approach to professional activities and achieving its maximum effectiveness in the future teachers' professional development) and motivation for pedagogical activities (tendency for continuous professional development, continuous improvement of the pedagogical skills level) of the future physical education teachers. During the research it was established that the majority of the future physical education teachers (45\%) demonstrated the basic level of the formation of communicative skills, as well as of pedagogical reflection and motivation for professional activities. On the low level $34 \%$ of the respondents were found, on the sufficient one $-21 \%$ of the future physical education teachers.

Key words: image, professional image, pedagogical image, future teachers, motivation, pedagogical reflection, communicative skills.

\section{Постановка проблеми в загальному} вигляді. Актуальність дослідження пов'язана 3 реформуванням освіти, що зумовлює розвиток цілісної, висококультурної особистості, яка перебуває в гармонії з навколишнім світом, гнучко орієнтується в нових умовах, прагне до максимальної реалізації власних можливостей у професійній діяльності. Це підсилює увагу до індивідуальності майбутніх учителів і призводить до того, що високий рівень сорормованості педагогічного іміджу може бути одним із найважливіших показників їх професійного становлення, оскільки визначає високий рівень комунікатив- них умінь, професійної мотивації та педагогічної рефрлексії.

Аналіз останніх досліджень і публікацій. Теоретичним базисом розв'язання проблеми формування педагогічного іміджу майбутніх учителів стали роботи таких учених, як О. Грейліх, Н. Гузій, Т. Довга, В. Ісаченко, Л. Кайданова, О. Мармаза, В. Олексенко, Н. Прус, Н. Савченко та ін. Професійну підготовку майбутніх учителів у роботах висвітлювали такі науковці: І. Бех, І. Богданова, А. Богуш, Н. Волкова, І. Зимня, Е. Карпова, Н. Кузьміна, 3. Курлянд, О. Леонтьєв, А. Маркова, Л. Мітіна, І. Підласий, А. Реан, О. Семеног, 
В. Сластьонін, Л. Спірин, Р. Хмелюк, О. Чебикін, О. Щербаков, В. Якунін та ін. Сутність і специфріку підготовки вчителів фрізичної культури висвітлено в дослідженнях А. Воронова, Є. Жуковського, Г. Омельяненко, Л. Сущенко, В. Троценко й ін. Проте, незважаючи на достатню кількість наукових досліджень, присвячених вивченню різноманітних аспектів понять «імідж», «профресійний імідж», «педагогічний імідж», «імідж учителя» в межах фрілософського, соціологічного, психологічного та педагогічного напрямів (І. Альошина, М. Бєляєв, І. Володарська, О. Затворнюк, М. Мазоренко, Н. Смирнов, В. Орєшкін, О. Панасюк, А. Панфрілова, В. Шепель та ін.), питання розгляду фрормування педагогічного іміджу майбутніх учителів залишається відкритим.

Виділення не вирішених раніше частин загальної проблеми. Підготовка майбутніх учителів повинна створювати максимально сприятливі умови для їх професійного становлення й відповідати реаліям сьогодення, що пов'язані з ресрормуванням освіти. Попри наявність наукових розвідок із зазначеної проблеми, теоретичні основи педагогічного іміджу потребують вивчення. Особливої значущості набуває питання про важливість комунікативних умінь, педагогічної ресрлексії та професійної мотивації під час фрормування педагогічного іміджу майбутніх учителів.

Мета статті полягає у висвітленні й аналізі результатів діагностики рівнів акмеологічного становлення майбутніх учителів після проведення фрормувального експерименту.

Виклад основного матеріалу. Етимологічно термін «педагогічний імідж» походить від базового поняття «імідж», яке загалом визначається в психолого-педагогічній літературі (Т. Довга, О. Мармаза, В. Олексенко) як думка про особу, групу людей, сорормована в психіці цих людей, образ цієї особи, що виник у результаті їх прямого контакту або внаслідок отриманої про цю людину інфрормації від інших людей [3]; багатоаспектне поняття, яке означає управління увагою, спосіб соціального програмування поведінки людини, соціальну роль, спосіб самовдосконалення, фрорму публічного самовираження [6]; загальний механізм особистості, спрямований на діяльність, що являє собою фрундаментальну морфему психологічної активності [7].

Уважаємо за необхідне наголосити, що проведений аналіз дефініції поняття «імідж» засвідчив, що в науково-довідковій літературі та в розмовному мовленні існують близькі за значенням багатозначні синонімічні ряди, такі як педагогічний імідж, професійний імідж, імідж учителя. Так, «педагогічний імідж» (О. Грейліх, Н. Гузій, Л. Кайданова) тлумачать як емоційно забарвлений стереотип сприйняття образу педагога у свідомості студентів, колег, соціального оточення, у масовій свідомості
[1]; полісемантична категорія, яка характеризує стиль професійно-педагогічної діяльності, манеру спілкування, уміння індивідуалізувати свій образ, надавати йому естетичної виразності [2]; один із основних засобів реалізації принципів навчання й виховання, які тісно пов'язані з його професійною компетентністю, педагогічною майстерністю, психолого-педагогічною культурою, особистісними та профресійно значущими якостями [5].

Проведений аналіз наукових розвідок дає змогу стверджувати, що під професійним іміджем учителя розуміють емоційно забарвлений психічний образ, який склався в масовій свідомості та має риси стереотипу, що легко трактується й відчутно впливає на пояснювальні механізми свідомості, поведінки й вибір іншої людини як споживача сорери послуг [4]; складне утворення, зумовлене особливостями професійної діяльності та соціальними ролями, що виконує особистість [9].

Отже, окреслені визначення дали можливість стверджувати, що формування педагогічного іміджу майбутніх учителів потребує свідомого підходу й постійного управління ним, яке передбачає імплементацію бажаних характеристик у його поведінкову фрорму, мотиваційно-ціннісну орієнтацію та комплексну систему оцінювання. Зважаючи на це, фрормування педагогічного іміджу майбутніх учителів цілком залежить від таких чинників, як комунікативні вміння, педагогічна ресрлексія та професійна мотивація, що віддзеркалюють змістове наповнення й семантику тлумачення означених понять.

Різні аспекти рефлексії розкриті в наукових працях таких учених, як Б. Ананьєв, Дж. Дьюї, Л. Виготський, С. Рубінштейн та ін. Пояснювальні словники тлумачать поняття рефлексії як самоаналіз, думки людини про власний стан душі, рефлексію, а також дослідження процесу пізнання. У психологічній літературі, з одного боку, рефлексія визначається як якість, необхідна профресіоналам, оскільки забезпечує процес саморозвитку, що дає їм змогу ефективно й адекватно реалізувати себе та свої здібності. Рефлексія (лат. reflexio - повернення назад, рефлексія; думати, розмірковувати, споглядати) з погляду психології характеризується як самоаналіз, постійний аналіз, розуміння себе, власної діяльності й засобів досягнення бажаного результату; рефрлексія пояснюється як акт пізнання, предметом якого $€$ власний духовний світ.

Психолого-педагогічна сутність рефрлексії висвітлюється в численних працях вітчизняних і зарубіжних учених: Л. Алексеєвої, І. Зимньої, Л. Мітіної, П. Підкасистого, І. Підласого та ін. Варто підкреслити, що в контексті сучасної модернізації освіти, коли вища освіта спрямована на підготовку конкурентоспроможного спеціаліста, викладача з новим стилем творчого про- 
фресійного мислення, високий рівень здатності до педагогічної рефлексії може бути одним із найважливіших показників майстерності вчителя, оскільки визначає високий рівень самооцінки, самоаналізу та самокорекції [15].

Розвинена здатність до професійної рефлексії $€$ передумовою самоосвіти вчителя, творчого пошуку, розвитку індивідуального стилю педагогічної діяльності. Основою цього є дослідження Г. Полякової (2006), яка визначає педагогічну рефлексію як один із механізмів саморегуляції вчителя, здатність до самоаналізу, отже, здатність критично переосмислювати власний досвід. Р. Тур (2004) стверджує, що педагогічна рефлексія функціонує як аналіз викладачем власного психічного стану, який спрямований на його професійне самовдосконалення та $є$ ключовим моментом розвитку особистості. Л. Гапоненко (2002), у свою чергу, розглядає розвиток педагогічної реолексії як психологічний механізм корекції професійної поведінки в педагогічному спілкуванні. На думку Н. Кічук (2019), педагогічна рефрлексія - це вияв педагогічних здібностей майбутніх учителів, передумова гарантованого успіху в оволодінні педагогічною діяльністю, демонстрація творчості й ініціативи, «зменшення дистанції» до педагогічної обдарованості.

Отже, педагогічна рефрлексія - це усвідомлення вчителем себе як суб'єкта діяльності: своїх особливостей, здібностей, того, як усе це сприймається учнями, батьками, колегами, адміністрацією. Водночас це усвідомлення цілей і структури діяльності вчителя, засобів її оптимізації. Отже, беручи до уваги вищезазначене, ми доходимо висновку, що педагогічна рефлексія сприяє як творчому підходу до професійної діяльності, так і досягненню її максимальної ефективності та результативності в профресійному становленні майбутніх учителів [15].

Незважаючи на достатню кількість психологопедагогічних досліджень підготовки майбутнього вчителя до комунікативної діяльності (І. Бех, Н. Бібік, А. Бойко, Н. Бутенко, Н. Волкова, Ю. Вторнікова, К. Дмитренко, В. Кан-Калік, А. Капська, С. Левченко, О. Романова та ін.), питання фрормування комунікативних умінь і навичок у майбутніх учителів залишається відкритим. Зазначимо, що під комунікативними вміннями розуміють індивідуально-психологічні особливості особистості, які забезпечують ефективність їі спілкування та співіснування 3 іншими людьми. До комунікативних належать такі вміння: ініціювати відкритість до контактів, демонструвати відгук на ініціативу інших; виразно повідомляти словами та мімікою свою готовність спілкуватися; уміння обмінюватися інфрормацією, вислухати, не перебиваючи, іншого, налагоджувати спільну взаємодію; уміння дорожити взаєминами, виявляти доступні вікові особливості, відданість, надійність, поступливість [13].

Формування вмінь, зокрема комунікативних, буде тим ефективніше, що глибше майбутній учитель оволодіє комунікативними знаннями та відповідними навичками - автоматизованими усвідомленими діями, що сприяють швидкому й точному відображенню комунікативних ситуацій на уроках. В аспекті дослідження слушним $€$ висновки В. Кан-Каліка (1987), у якому науковець обґрунтував перелік комунікативних умінь педагога, що є базисними для формування професійно-педагогічної комунікації майбутніх учителів: спілкування 3 людьми та управління ними; оперативне орієнтування в умовах спілкування, що здійснюється; планування та здійснення системи комунікації, зокрема її важливої ланки - мовленнєвого впливу; відчуття й підтримання зворотного зв'язку в комунікації [13].

Проблему мотивації як категорію наукового апарату сучасної психології досліджували Л. Божович, Л. Виготський, Е. Зеєр, Є. Ільїн, Е. Клімов, К. Левін, О. Леонт'єв, С. Максименко, А. Маркова, А. Маслоу С. Рубінштейн, Ю. Чебакова, П. Якобсон та ін. Відомо, що будь-яка діяльність, у тому числі навчально-пізнавальна та професійна, спонукається водночас низкою мотивів, які ієрархічно пов'язані один із одним. Сам термін «мотив» у багатьох теоретичних підходах трактується як усвідомлення суб'єктом мети його дії; потяги, що $€$ неусвідомленими, - ті, якими зумовлюються зовнішні прояви поведінки; зовнішні щодо суб'єкта стимули. Отже, поняття «мотив» можна трактувати як стійку особистісну диспозицію або як причину поведінки чи окремих дій особи [14].

Як визначає Н. Олійник, мотиви підпорядковуються потребам, які, у свою чергу, фрормують зовнішню і внутрішню мотивацію, спрямовану на розвиток професійної компетентності педагогів. Дослідниця О. Сагач стверджує, що мотивація - це бажання, спонукання, стимули, які призводять до активності людини та визначають їі спрямованість. Мотивація внутрішньо спонукає до активності, поєднує змістову та динамічну сторони як актуального, так і потенційного змісту [11]. У зв'язку з цим структура мотивації складається із цілі, спрямування, готовності до дії, упевненості в правильності дій. 3 іншого боку, під час підготовки майбутніх учителів необхідно залучити їх до усвідомлення мотивів як потреби (О. Леонтьєв), наміру (Л. Божович, К. Левін), збудження (В. Семиченко), стану (А. Меєрович), емоції (Б. Додонов), оцінювання (В. Асеєв, П. Якобсон), особистісних диспозицій (К. Платонов), активності (Є. Ільїн).

Варто наголосити, що мотиви педагогічної діяльності - спонукання, яке пов'язане з їі здійсненням, чи то внутрішня потреба працювати в галузі цього предмета, чи то потреба працювати 
3 людьми, що базується на усвідомленні своїх педагогічних здібностей [14]. Під навчально-професійною мотивацією вчені розуміють систему мотивів, цілей, потреб, спонукань, які зумовлюють прояви навчальної активності й активних дій щодо оволодіння професією, у тому числі й професією вчителя. Це дає можливість стверджувати, що під час формування мотивації майбутніх учителів відбувається прагнення до постійного профресійного розвитку, неперервного досягнення високого рівня педагогічної майстерності [11].

Наступник кроком реалізації мети було здійснення діагностики в другому семестрі 2019-2020 навчального року серед здобувачів вищої освіти 1 року навчання Інституту фрізичної культури, спорту та реабілітації Державного закладу «Південноукраїнський національний педагогічний університет імені К. Д. Ушинського» (48 осіб, спеціальність 014 «Середня освіта (Фізична культура)». Так, 3 метою визначення рівнів сорормованості комунікативних умінь майбутніх учителів фрізичної культури використано діагностику ефрективності педагогічних комунікацій [12]. Сутність методики діагностики ефективності педагогічних комунікацій полягає у виявленні «аудиторної атмосфери», активності, вираження пізнавального інтересу майбутніх учителів фрізичної культури, а також деяких проявів стилю педагогічної діяльності. Для діагностики мотивації майбутніх учителів фрізичної культури використано методику «Мотивація успіху і боязнь невдач» А. Реана. Зазначена методика покликана визначити домінуючу мотивацію залежно від такої типології: мотивація досягнення успіху й уникнення невдачі [10]. Стійку потребу в рефлексії власних дій у житті та профресійній діяльності в майбутніх учителів фрізичної культури діагностовано за допомогою методики «Визначення рівня сорормованості педагогічної рефлексії» [8].

Результати діагностування рівнів сорормованості комунікативних умінь, педагогічної рефлексії та мотивації на педагогічну діяльність майбутніх учителів фрізичної культури подано в таблиці 1.

Як бачимо з таблиці, за рівнем сформованості комунікативних умінь достатній рівень засвідчили 24\% респондентів, базовий - 48\%, низький рівень - 28\% респондентів. Достатній рівень мотивації засвідчили 26\% респондентів, базовий - 50\%, низький - 24\% майбутніх учителів. Педагогічну рефрлексію на достатньому рівні діагностовано в 13\% респондентів, базовий - 37\%, низький - 50\% від загальної кількості майбутніх учителів фрізичної культури.

Узагальнені результати сорормованості чинників, що впливають на фрормування педагогічного іміджу майбутніх учителів фрізичної культури, унаочнено на рисунку 1.

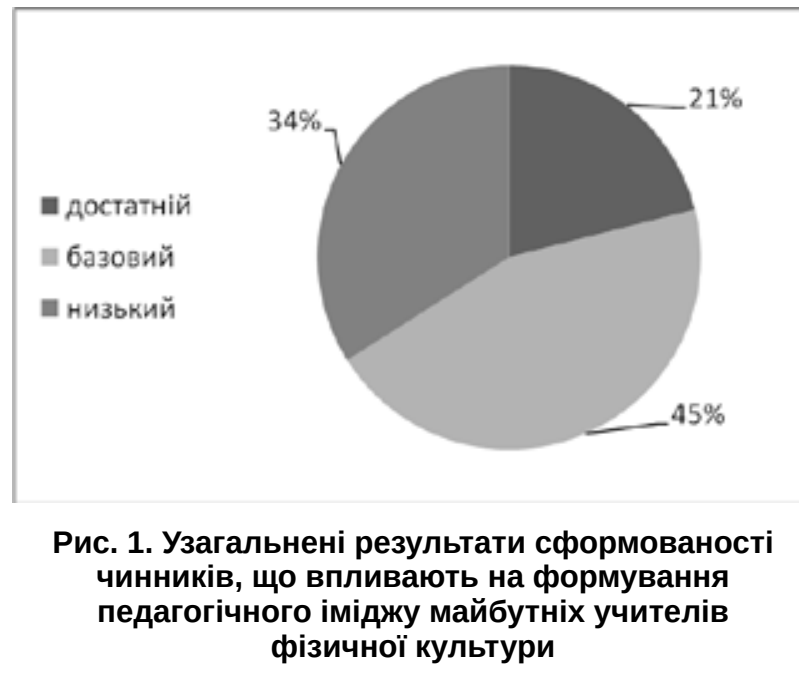

Отже, як видно з рисунку 1, найбільша кількість майбутніх учителів фрізичної культури (45\% від загальної кількості) засвідчила базовий рівень сорормованості комунікативних умінь, педагогічної рефлексії та мотивації на педагогічну діяльність. На низькому рівні виявлено 34\% осіб від загальної кількості респондентів; 21\% респондентів опинилися на достатньому рівні сорормованості означених чинників, що впливають на формування педагогічного іміджу майбутніх учителів фрізичної культури.

Висновки. Проведений аналіз теоретичних засад френомена «педагогічний імідж» не вичерпує всіх аспектів визначеної проблеми. Аналіз одержаних результатів свідчить про необхідність подальшого фрормування педагогічного іміджу майбутніх учителів фрізичної культури в умовах університетської освіти. Саме тому перспективу подальших наукових розвідок убачаємо в обґрунтуванні педагогічних умов фрормування педагогічного іміджу майбутніх учителів фрізичної культури під час професійного становлення.

Результати діагностики рівнів сфрормованості комунікативних умінь,

Таблиця 1 педагогічної рефлексії та мотивації на педагогічну діяльність

\begin{tabular}{|l|c|c|c|}
\hline \multirow{2}{*}{\multicolumn{1}{|c|}{ Чинники }} & \multicolumn{2}{c|}{ Рівні соромованості чинників, \% } \\
\cline { 2 - 4 } & достатній & базовий & низький \\
\hline Комунікативні вміння & 24 & 48 & 28 \\
\hline Мотивація & 26 & 50 & 24 \\
\hline Педагогічна ресрлексія & 13 & 37 & 50 \\
\hline
\end{tabular}




\section{БІБЛІОГРАФІЧНИЙ СПИСОК:}

1. Грейліх О. Психологія фрормування іміджу викладача вищого навчального закладу. Гуманітарний вісник Державного вищого навчального закладу «Переяслав-Хмельницький державний педагогічний університет імені Григорія Сковороди». ПереяславХмельницький, 2010. Вип. 19. С. 294-299.

2. Гузій Н. Педагогічний профресіоналізм : історико-методологічні та теоретичні аспекти : монографія. Київ : НПУ імені М.П. Драгоманова, 2004. 243 с.

3. Довга Т. Імідж особистості як необхідна умова професійного становлення педагога. Теоретикометодичні проблеми виховання дітей та учнівської молоді. 2010. Вип. 14. Кн. 1. С. 66-75.

4. Ісаченко В.В. Формування професійно-педагогічного іміджу майбутніх викладачів вищої школи : автореср. дис. ... канд. пед. наук : 13.00.04. Одеса, 2004. 16 C.

5. Кайданова Л. Просесійна компетентність та імідж сучасного викладача. Гуманітарній вісник. 2009. № 17. C. 24-29.

6. Мармаза О. Імідж як спосіб професійної соціалізації керівника навчального закладу. Педагогіка формування творчої особистості у вищій $і$ загальноосвітній школах. 2013. Вип. 33. С. 263-269.

7. Олексенко В. Формування професійного іміджу сучасного вчителя. Проблеми освіти. 2015. Вип. 84. C. $258-263$.

8. Орлова И.В. Тренинг профрессионального самопознания: теория, диагностика и практика педагогической рефрлексии. Санкт-Петербург : Речь, 2006. 128 с.
9. Прус Н.О. Формування професійного іміджу майбутнього викладача іноземних мов : авторефр. дис. ... канд. пед. наук : 13.00.04. Дніпро, 2017. 21 с.

10. Реан А.А. Психология и психодиагностика личности : теория, методы исслед., практикум: арсенал практ. психолога. Прайм-Еврознак, 2008. 255 с.

11. Сагач О. Мотивація як складова професійного розвитку майбутнього вчителя. 2019. C. 105-110. URL: http://pedosv.kpnu.edu.ua/article/ viewFile/187545/416743-1.

12. Фетискин Н.П., Козлов В.В., Мануйлов Г.М. Социально-психологическая диагностика развития личности и малых групп. Москва: Изд-во Института психотерапии, 2005. 490 c.

13. Hurin R.S. Diagnosis of formation levels of future teachers' communicative skills. Materials of the $X V I$ International scientific and practical Conference Prospects of world science - 2020, July 30 - August 7, 2020 : Sheffield. Science and education LTD. P. 58-60.

14. Hurin R.S. Motivation in the professional development of a future teacher. Impatto dell'innovazione sulla scienza : aspetti fondamentali e applicati : Raccolta di articoli scientifici « $\Lambda^{\prime} \mathrm{O} Г \mathrm{\Sigma} \Sigma$ » con gli atti della Conferenza scientifica e pratica internazionale (T. 2), 26 giugno 2020. Verona, Italia : Piattaforma scientifica europea. P. 11-12.

15. Hurin R.S. Pedagogical reflection of the future teacher. Modern science : problems and innovations. Abstracts of the $3^{\text {rd }}$ International scientific and practical conference. SSPG Publish. Stockholm, Sweden. 2020. P. 289-292. 